JARES, Vol. 4 No. 1 March, 2019; p-ISSN: 2502-826X; e-ISSN: 2503-1163

Copyrights@ Balitar Islamic University, Blitar, Indonesia;

https://ejournal.unisbablitar.ac.id/index.php/jares

\author{
Citation: Suprianto, S., Andari, B., \& Sulistyawati, Y. (2019). CALCULATION OF \\ PRODUCTION COST IN UD. USAHA BARU WITH FULL COSTING METHOD. \\ JARES (Journal of Academic Research and Sciences), 4(1), 28-42.
}

https://doi.org/10.30957/jares.v4i1.688

\title{
CALCULATION OF PRODUCTION COST IN UD. USAHA BARU WITH FULL COSTING METHOD
}

\author{
Suprianto ${ }^{1}$, Bina Andari ${ }^{2}$, Yely Sulistyawati ${ }^{3}$ \\ Faculty Of Economics, Balitar Islamic University \\ Email. suprianto@unisbablitar.ac.id, binaandari@unisbablitar.ac.id, \\ yelysulis64@gmail.com
}

\begin{abstract}
This study aims to evaluate the calculation of cost of production. The accuracy of the calculation of cost of production is influenced by the suitability in the accumulation and calculation of production costs which includes the cost of raw materials, direct labor costs and other costs (factory overhead costs). This research was conducted at UKM UD. Usaha Baru which aims to determine the calculation of cost of production at UD. Usaha Baru and to find out whether the calculation of cost of production is in accordance with the full costing method. The technique (method) of data analysis used in this study is quantitative analysis. Data collection techniques use interview techniques directly to obtain information from the number of units of monthly production, raw material costs, direct labor costs, and factory overhead costs, as well as other information relating to the calculation of cost of production. Based on the evaluation results for the calculation of raw material costs and labor costs are in accordance with the full costing method. However, the calculation of factory overhead costs is not in accordance with the full costing method because there are costs that have not been included in the calculation of production costs.
\end{abstract}

\section{Keywords: Evaluation, Cost of Production}

\section{INTRODUCTION}

Small and Medium Enterprises (SMEs) that have been established certainly want to develop and continue to maintain the viability of their business, the smoothness and success of a business depends on the ability of business owners to make decisions. The role of accounting is to provide information as a basis for business decision making. Accounting information can be a reliable basis for decision making in business management. Therefore, accounting information has an important role for business people in achieving the success of their business, including for small and medium enterprises (SMEs) (Huda, Anam Miftakhul. Farida, 2018)

Calculation of production costs is one of the important things in an effort to know the purpose of a business. In determining the cost of production must pay attention to the elements of what costs are included in the cost of the product and allocate these cost elements appropriately. Thus with the calculation of the right cost of production, it will result in the determination of the right selling price, so that it can generate profits as expected (Kurniasari, Dita, Huda, 2018). 
JARES, Vol. 4 No. 1 March, 2019; p-ISSN: 2502-826X; e-ISSN: 2503-1163

Copyrights@ Balitar Islamic University, Blitar, Indonesia;

https://ejournal.unisbablitar.ac.id/index.php/jares

Citation: Suprianto, S., Andari, B., \& Sulistyawati, Y. (2019). CALCULATION OF

PRODUCTION COST IN UD. USAHA BARU WITH FULL COSTING METHOD. JARES (Journal of Academic Research and Sciences), 4(1), 28-42.

https://doi.org/10.30957/jares.v4i1.688

Determining the cost of production can be done with two approaches, namely the full costing method and variable costing. Full costing treats all production costs as a base price regardless of whether the costs are variable or fixed. While the variable costing is only the production costs that vary according to the output required as the cost of goods (Ika Yulianti, Endah Masrunik, Anam Miftakhul Huda, 2018). Generally consists of direct raw materials, direct labor, and variable overhead.

UD. Usaha Baru is a Small and Medium Business engaged in a mini pump assembly business (first) that is used to sell BBM retail. In determining the cost of production in an SME that is still in the developing stage in general the use of methods in calculating the cost of production is still very simple or not in accordance with accounting theory.

Based on this understanding it can be concluded that the cost of production is the costs that affect the production process which includes fixed costs and variable costs

\section{RESEARCH METHODS}

This research was conducted at UKM UD. Usaha Baru as the object of research located in Slorok Village, Garum District, Blitar Regency. UD. Usaha Baru is a Small and Medium Enterprises (UKM) mini pump assembly (first) that is used for fuel oil sales.

The type of research in this proposal is evaluative. Evaluative research is research that is used to support the selection of several alternative actions in the process of making business decisions. This study assesses the effectiveness of an action, activity, or program (Indriantoro \& Supomo, 2009: 24).

In this study, the data used are primary data and secondary data. Primary data is a source of research data obtained directly from the original source (not through intermediaries), while secondary data is a research data source obtained by researchers indirectly through intermediary media. (Indriantoro \& Supomo, 2009: 146).

The data collection technique used is the interview method and documentation. The interview method is a technique of collecting data in a survey method that uses questions verbally to the subject of research (Indriantoro \& Sumpomo, 2009: 152). while the documentation method is a type of research data which includes: invoices, journals, letters, minutes of meetings, memos, or in the form of program reports (Indriantoro \& Sumpomo, 2009: 146).

The data analysis method used is quantitative methods. Quantitative method is a method of analyzing data that can be proven by numbers and in its calculations using formulas. 
JARES, Vol. 4 No. 1 March, 2019; p-ISSN: 2502-826X; e-ISSN: 2503-1163

Copyrights@ Balitar Islamic University, Blitar, Indonesia;

https://ejournal.unisbablitar.ac.id/index.php/jares

Citation: Suprianto, S., Andari, B., \& Sulistyawati, Y. (2019). CALCULATION OF

PRODUCTION COST IN UD. USAHA BARU WITH FULL COSTING METHOD.

JARES (Journal of Academic Research and Sciences), 4(1), 28-42.

https://doi.org/10.30957/jares.v4i1.688

The steps of data analysis and analysis tools used in this study are as follows:

1. Identify and collect data on costs contained in SMEs UD. Usaha Baru for the past 2 months.

2. Identifying factory overhead costs that occur in the company according to their behavior in relation to changes in production volume, namely evaluating and classifying factory overhead costs (BOP) into fixed overhead costs and variable overhead costs.

3. Calculation of cost of production at the company

a. Determining material costs

Raw material costs include the cost of all materials identified by changes in the type of product.

b. Direct Labor Costs (BTKL)

Direct labor costs are labor costs that directly carry out processing of raw materials into final products, and an important part of all labor costs needed to make these products.

c. Determining Factory Overhead Cost (BOP)

Calculation of factory overhead costs (indirect production costs) to products based on the amount of production by calculating the percentage of consumption of factory overhead on each product. Calculation with the following formula:

Production amount per product

Loading $=$ X $100 \%$

Total production of all products

4. Determining Cost of Production

a. Calculate production costs with the full costing method

b. Calculate the cost of production

5. Evaluating Cost of Production

Comparing the cost of production of SMEs with the cost of production of the research results.

\section{RESULTS AND DISCUSSION}

UD. Usaha Baru is a Small and Medium Enterprises (UKM) located in Slorok Village, RT. 03 RW. 01 Garum District, Blitar Regency. This UKM was established on November 26, 2017 by Mr. Solikin. Small and Medium Enterprises in this first assembly have been running for about 2 years. This first business is expected to help fuel retail sales in various groups. The first product produced is used alone by selling retail on the edge of the highway. This is used for the first trial, after being deemed feasible, the first official product is sold with various models and prices. UD. Usaha Baru is an individual or private owned Small and Medium Enterprises 
JARES, Vol. 4 No. 1 March, 2019; p-ISSN: 2502-826X; e-ISSN: 2503-1163

Copyrights@ Balitar Islamic University, Blitar, Indonesia;

https://ejournal.unisbablitar.ac.id/index.php/jares

Citation: Suprianto, S., Andari, B., \& Sulistyawati, Y. (2019). CALCULATION OF

PRODUCTION COST IN UD. USAHA BARU WITH FULL COSTING METHOD. JARES (Journal of Academic Research and Sciences), 4(1), 28-42. https://doi.org/10.30957/jares.v4i1.688

(SMEs).

Location of the UD assembly. New Business is in Slorok Village RT. 03 RW. 01 Garum District, Blitar Regency, East Java Province. UD. Usaha Baru has an organizational structure that is organized neatly and complex and has the duties and authorities of each part. The following organizational structure is owned by UD. New business, especially in the assembly.

\section{Employment and Marketing at UD. Usaha Baru}

Employment is a major problem in operational activities, because most of its activities are carried out by human resources, both in the field of assembly and marketing. In dealing with labor problems, SMEs always provide motivations to maintain the quality of work of employees in assembly and marketing. This is mainly done in the field of assembly, where the quality of work will greatly affect the product to be produced. The number of workers at UD. Usaha Baru is 5 people.

Marketing activities are a function of the main activities carried out by Small and Medium Enterprises (SMEs) to develop and to maintain the viability of these SMEs (Huda \& Martanti, 2018). As for some regions or regions carried out by UD. Usaha Baru to sell the results of its mini pump assembly (first) covers all areas in East Java.

\section{Assembly Activities and Process UD. Usaha Baru}

a. Assembly

There are results of the assembly produced by UD. Usaha Baru are as follows:

1. Mini pump (first) 1 Nozzle

2. Mini pump (first) 2 Nozzle

3. Mini pump (first) 3 nozzle

b. Assembling Process

The assembly process is the process by which assembling or assembling into a single unit of finished goods. The process carried out at UD. Usaha Baru starts from:

1. Preparation of Raw Materials

This process is carried out by UD. Usaha Baru in mini pump assembly to check that every mini pump that will be assembled has all the raw materials available. Each first unit requires raw materials that are not the same, because there are 3 types of mini pumps, namely 1 nozzle, 2 nozzles, and 3 nozzles.

The main raw material needed in this assembly is "bok" for a mini pump, which is obtained from the agent "bok" directly, so as to get a lower price. Other raw materials needed in this assembly include:

CPU and Dispplay Strainar / Suningan 
JARES, Vol. 4 No. 1 March, 2019; p-ISSN: 2502-826X; e-ISSN: 2503-1163

Copyrights@ Balitar Islamic University, Blitar, Indonesia;

https://ejournal.unisbablitar.ac.id/index.php/jares

Citation: Suprianto, S., Andari, B., \& Sulistyawati, Y. (2019). CALCULATION OF

PRODUCTION COST IN UD. USAHA BARU WITH FULL COSTING METHOD. JARES (Journal of Academic Research and Sciences), 4(1), 28-42.

https://doi.org/10.30957/jares.v4i1.688

Suction Oil Faucet Pump

Accu measuring 200 liter drum measuring

Travo S.A 4 meter hose

OPW Nozzle set cable

Doubled Nepel $3 / 4$ meter Check (oil stop)

Doubled Nepel 1 Fire (extinguisher)

Hose in 3/4 meter 2 meter outer hose

2. Assembly Stage

At this stage, the mini pump assembly is carried out for a maximum of 3 days for the mini nozzle pump assembly. The stages include:

a) Assembling the oil pump, glue and neatly arranged so that it can be attached to the hose to the drum until it's finished.

b) Assembling the display to "punch" the mini pump together with the CPU assembly. Both are glue and affixed with a "bolt" with the appropriate bolt.

c) Cable assembly, this assembly is used to turn on the CPU, Display, with Travo 5A until it turns on properly. If it hasn't been able to ignite properly, it must be repeated until it lights up perfectly.

d) Assembly on Accu, this assembly is done because it is used as a tool to measure a liter of oil entering and leaving the mini pump. In this assembly you need extra level of accuracy because every liter of oil or fuel that is released must be in accordance with the dosage set by the SME UD. New Business.

3. Finishing stage

Mini Pump Finishing Stage is a process where goods that have been assembled neatly and have $95 \%$ completed are ready to be checked for their feasibility to be marketed to the public. If at this stage it turns out there is an error or there is an incompatibility in the assembly, it will be re-examined in a mini pump assembly that is in accordance with the eligibility criteria in the distribution of mini pumps.

\section{Calculation of Cost of Production}

Calculation of cost of production is one of the important elements that companies use to get more profits. What is meant by cost of production is the calculation of costs incurred when producing a product, starting from the procurement of raw materials to the final process of products that are ready for sale in the market.

Calculation of cost of goods manufactured by UD. Usaha Baru determines three components in it, namely material costs, labor costs, and factory overhead costs. Material costs at UD. Usaha Baru are divided into two, namely the cost of raw materials and the cost of supporting materials 
JARES, Vol. 4 No. 1 March, 2019; p-ISSN: 2502-826X; e-ISSN: 2503-1163

Copyrights@ Balitar Islamic University, Blitar, Indonesia;

https://ejournal.unisbablitar.ac.id/index.php/jares

Citation: Suprianto, S., Andari, B., \& Sulistyawati, Y. (2019). CALCULATION OF

PRODUCTION COST IN UD. USAHA BARU WITH FULL COSTING METHOD.

JARES (Journal of Academic Research and Sciences), 4(1), 28-42.

https://doi.org/10.30957/jares.v4i1.688

or the cost of supporting materials. For auxiliary materials will be included in the factory overhead costs. UD. Usaha Baru uses a full costing method approach, because it takes into account all production costs without separating variable costs. Following the results of the analysis obtained from UD. Usaha Baru:

\section{Assembly Results}

UD. Usaha Baru as a whole has produced various kinds of products, where the products are divided into three types of products, namely 1 nozzle, 2 nozzles, and 3 nozzles. UD. Usaha Baru certainly has a quantity in product assembly in 2018 which will later be used as the basis for calculating the amount of raw material costs in the next period.

Based on the data obtained it can be seen that the first assembly of products for one year amounted to 2 units for assembling 1 nozzle, 40 units for assembling 2 nozzles, and 3 units for assembling 3 nozzles. This amount is the result of production from UD. Usaha Baru for one year.

\section{Raw Material Costs}

Raw material costs according to accounting are costs incurred to obtain raw materials and to place them in a state ready for processing. The raw material itself is the basic material that will be used to produce a finished product. Raw materials in mini pump assembly (first) at UD. This new business is directly divided into raw material costs per mini pump assembly per unit.

Table 1

Raw Material Costs UD. Usaha Baru 2018

\begin{tabular}{|c|c|cr|}
\hline $\begin{array}{c}\text { PRODUTS } \\
\text { TYPE S }\end{array}$ & Assembly Number & \multicolumn{2}{|c|}{$\begin{array}{c}\text { Amount of Raw Material } \\
\text { Costs }\end{array}$} \\
\hline 1 Nosel & 2 & $\mathrm{Rp}$ & 12.550 .000 \\
\hline 2 Nosel & 40 & $\mathrm{Rp}$ & 502.000 .000 \\
\hline 3 Nosel & 3 & $\mathrm{Rp}$ & 71.400 .000 \\
\hline Jumlah & $\mathbf{4 5}$ & $\mathrm{Rp}$ & $\mathbf{5 8 5 . 9 5 0 . 0 0 0}$ \\
\hline
\end{tabular}

Source : UD. Usaha Baru

Based on the calculation of raw material costs from attachment 1 and from the table above the calculation of raw material costs at UD. New business is appropriate, which is determined by multiplying and adding up the cost of raw materials per mini pump unit with the total cost per assembly. 
JARES, Vol. 4 No. 1 March, 2019; p-ISSN: 2502-826X; e-ISSN: 2503-1163

Copyrights@ Balitar Islamic University, Blitar, Indonesia;

https://ejournal.unisbablitar.ac.id/index.php/jares

Citation: Suprianto, S., Andari, B., \& Sulistyawati, Y. (2019). CALCULATION OF

PRODUCTION COST IN UD. USAHA BARU WITH FULL COSTING METHOD.

JARES (Journal of Academic Research and Sciences), 4(1), 28-42.

https://doi.org/10.30957/jares.v4i1.688

\section{Direct Labor Costs}

According to Mulyadi (2015: 321), labor costs in the cost of process method consist of direct labor costs and indirect labor costs. Direct labor costs are costs that labor is incurred in the production process. Direct labor rates at UD. The New Business has been determined by the UKM which is divided into 2, namely: the processing cost of Rp. 45,000, - per mini pump unit and assembly parts costs Rp. 55,000 per mini pump unit.

\section{Factory Overhead Costs}

Factory overhead costs are costs other than those included in raw material costs and direct labor costs. Own factory overhead costs are costs incurred due to production activities, UD factory overhead costs. New businesses include:

\section{a. Helper Material Costs}

Helper costs or auxiliary costs are materials that stick to one with finished goods and have a relatively lower value compared to the value of the raw material or the main material used in making a finished item. Cost of auxiliary materials in assembling products at UD. Usaha Baru is a sticker. Helper usage costs per product unit at UD. Usaha Baru Rp. 150,000 per unit of product produced.

b. Indirect Labor Costs

Indirect labor costs are all material wages paid to employees of the production department who have functions not directly related to the production process. The table below is an allocation obtained from SMEs with calculations in accordance with the provisions of the SME policy UD. Usaha Baru

Table 2

Indirect Labor Costs per Product Type 2018

\begin{tabular}{|c|c|cr|}
\hline $\begin{array}{c}\text { Types of } \\
\text { products }\end{array}$ & $\begin{array}{c}\text { Number of Prod uction } \\
\text { Units }\end{array}$ & \multicolumn{2}{|c|}{ Total Usage } \\
\hline 1 Nosel & 2 & $\mathrm{Rp}$ & 100.000 \\
\hline 2 Nosel & 40 & $\mathrm{Rp}$ & 900.000 \\
\hline 3 Nosel & 3 & $\mathrm{Rp}$ & 200.000 \\
\hline Jumlah & 45 & $\mathrm{Rp}$ & 1.200 .000 \\
\hline
\end{tabular}

Source : UD. Usaha Baru

c. Cost of depreciation

Production costs in assembly due to the passage of time at UD. Usaha Baru are machine depreciation costs, building depreciation, and depreciation of vehicles. The depreciation method used is a straight line method. Depreciation of machinery 
includes depreciation of group 1 not buildings with a 4-year useful life at a rate of $25 \%$. While the depreciation of the building includes the depreciation of permanent building groups, with a useful life of 20 years or at a rate of $5 \%$. And machine depreciation includes depreciation of group 1 not buildings with a 4-year useful life at a rate of 25\%. (Mardiasmo, 2003: 138). Following is the depreciation calculation as follows:
a) Machine depreciation per month is as follows $1 / 12 \times 25 \%$ x Rp. $5,000,000=$ Rp. 104,150 , -
b) Building Depreciation per month is as follows $1 / 12 \times 5 \%$ x Rp. $20,000,000=$ Rp. 83,400 , -
c) Vehicle Depreciation per month is as follows $1 / 12 \times 25 \% \times$ Rp. $60,000,000=$ Rp. 1,250,000, -

\section{d. Production Costs that Directly Require Cash Expenditures}

Production costs that directly require cash or cash disbursement in the production process are fuel costs, electricity costs, and water.

Fuel costs at UD. Usaha Baru is the cost of transporting raw materials and the cost of fuel used for mini pump assembly. The table below is an allocation obtained from SMEs with calculations in accordance with the policy provisions of SMEs.

\section{Table 3}

Fuel Cost per Prod uct Type 2018

\begin{tabular}{|c|c|cr|}
\hline $\begin{array}{c}\text { Types of } \\
\text { prod ucts }\end{array}$ & $\begin{array}{c}\text { Number of Prod uction } \\
\text { Units }\end{array}$ & \multicolumn{2}{|c|}{ Total U sage } \\
\hline 1 Nose1 & 2 & $R_{p}$ & 300.000 \\
\hline 2 Nose1 & 40 & $R_{p}$ & 6.000 .000 \\
\hline 3 Nosel & 3 & $R_{p}$ & 450.000 \\
\hline Jumlah & $\mathbf{4 5}$ & $R_{p}$ & $\mathbf{6 . 7 5 0 . 0 0 0}$ \\
\hline
\end{tabular}

Source : UD. Usaha Baru

The table above shows that the use of fuel costs is based on the assembly of products from each mini pump unit that is produced which is Rp. 6,750,000, - from these results obtained from the use of each product assembly, the data is directly obtained from SMEs.

Electricity costs are costs arising from the use of electricity by an SME or individual. Electricity costs that arise in an SME are basically mostly caused by product assembly parts because of the use of machinery for the process of assembling or processing raw materials. At UD. Usaha Baru electricity costs incurred are as follows: 
JARES, Vol. 4 No. 1 March, 2019; p-ISSN: 2502-826X; e-ISSN: 2503-1163

Copyrights@ Balitar Islamic University, Blitar, Indonesia;

https://ejournal.unisbablitar.ac.id/index.php/jares

Citation: Suprianto, S., Andari, B., \& Sulistyawati, Y. (2019). CALCULATION OF

PRODUCTION COST IN UD. USAHA BARU WITH FULL COSTING METHOD.

JARES (Journal of Academic Research and Sciences), 4(1), 28-42.

https://doi.org/10.30957/jares.v4i1.688

\begin{tabular}{|c|c|c|c|}
\hline $\begin{array}{l}\text { Types of } \\
\text { Produts }\end{array}$ & $\begin{array}{l}\text { Number of prod uction } \\
\text { Unit }\end{array}$ & \multicolumn{2}{|c|}{ Total usage } \\
\hline 1. Nose1 & 2 & $\mathrm{Rp}_{\mathrm{p}}$ & 84.000 \\
\hline 2 Nose1 & 40 & $\mathrm{Rp}$ & 1.665 .000 \\
\hline 3 Nose1 & 3 & $R_{p}$ & 126.000 \\
\hline Jumlah & 45 & $\mathbf{R}_{\mathbf{p}}$ & 1.875 .000 \\
\hline
\end{tabular}

Source : Data from UD. Usaha Baru

\section{e. Total Factory Overhead Cost}

The following is the total factory overhead collected by the author based on data obtained from UD. Usaha Baru

Table 5

Factory Overhead Cost

2018

\begin{tabular}{|c|c|c|c|}
\hline No. & Type of Fee & \multicolumn{2}{|r|}{ Total } \\
\hline 1. & TKIL & $\mathrm{RP}$ & 1.200 .000 \\
\hline 2. & Electricity, telephone, water costs & $\mathrm{Rp}$ & 1.875 .000 \\
\hline 3. & Engine maintenance costs & & - \\
\hline 4. & Building maintenance costs & & - \\
\hline 5. & Vehicle maintenance costs & & - \\
\hline 6. & Helper ma terial costs & Rp & 6.750 .000 \\
\hline 7. & Machine depreciation costs & $\mathrm{RP}$ & 1.249 .800 \\
\hline 8. & Building depreciation costs & Rp & 1.000 .800 \\
\hline 9. & Vehicle Depriciation costs & Rp & 15.000 .000 \\
\hline 10. & Fuel costs & $\mathrm{RP}$ & 2.250 .000 \\
\hline & TOTAL & $\mathbf{R}_{\mathbf{p}}$ & 29.325 .600 \\
\hline
\end{tabular}

Source : Data from UD. Usaha Baru

Based on the above data it can be seen that the number of factory overhead costs owned by UD. New Business Rp. $29,325,600$

\section{f. Comparison of Factory Overhead Costs}

Previously it was stated that maintenance costs are costs that are directly related to the cost of assembling the product. Where maintenance costs go into factory overhead. Costs that have not yet entered UD's factory overhead costs. New businesses are machine maintenance costs, building maintenance costs, and vehicle maintenance costs. The following is a comparison of the calculation of factory overhead costs from SMEs and calculations that are in accordance with the full costing method: 
JARES, Vol. 4 No. 1 March, 2019; p-ISSN: 2502-826X; e-ISSN: 2503-1163

Copyrights@ Balitar Islamic University, Blitar, Indonesia;

https://ejournal.unisbablitar.ac.id/index.php/jares

Citation: Suprianto, S., Andari, B., \& Sulistyawati, Y. (2019). CALCULATION OF

PRODUCTION COST IN UD. USAHA BARU WITH FULL COSTING METHOD. JARES (Journal of Academic Research and Sciences), 4(1), 28-42.

https://doi.org/10.30957/jares.v4i1.688

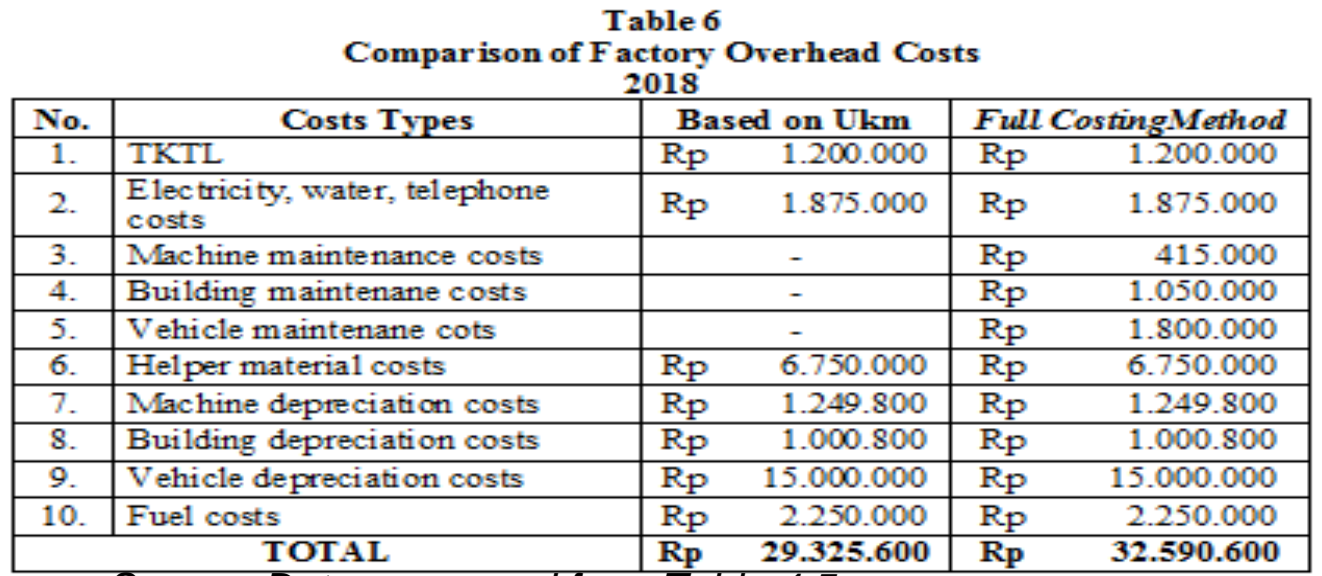

Source: Data processed from Table 4.5

\section{g. Determination of Cost of Production according to UKM}

Determination of cost of goods manufactured by UD. Usaha Baru is using the full costing method and the factory overhead allocation method to the type of product based on the number of product assemblies. The allocation calculation is done by calculating the percentage of consumption of factory overhead directly on the number of product assemblies each mini pump unit produced. For more details in the following table:

Table 7

Percentage of Factory Overhead Charges Accord ing to UKM in 2018

\begin{tabular}{|c|c|c|}
\hline $\begin{array}{c}\text { Products } \\
\text { Name }\end{array}$ & Production Total & A mount of loading \\
\hline 1 Nose1 & 2 & $4 \%$ \\
\hline 2 Nose1 & 40 & $89 \%$ \\
\hline 3 Nose1 & 3 & $7 \%$ \\
\hline Total & $\mathbf{4 5}$ & $\mathbf{1 0 0 \%}$ \\
\hline
\end{tabular}

Soure: Data from UD. Usaha Baru

From the table above it can be seen that the percentage of factory overhead costs at UD. New business allocated for each product assembly is $4 \%$ for 1 mini nozzle pump, $89 \%$ for 2 nozzle mini pumps, and $7 \%$ for 3 nozzle mini pumps.

Table 8

Loading of Factory Overhead Costs According to UKM in 2018

\begin{tabular}{|c|c|cr|}
\hline Product Name & Amount of Loading & \multicolumn{2}{|c|}{ Total A mount } \\
\hline 1 Nose1 & $4 \%$ & $\mathrm{Rp}$ & 1.173 .024 \\
\hline 2 Nose1 & $89 \%$ & $\mathrm{Rp}$ & 26.099 .784 \\
\hline 3 Nose1 & $7 \%$ & $\mathrm{Rp}$ & 2.052 .792 \\
\hline Total & $\mathbf{1 0 0 \%}$ & $\mathrm{Rp}$ & $\mathbf{2 9 . 3 2 5 . 6 0 0}$ \\
\hline
\end{tabular}

Source: Data from UD. Usaha Baru 
In the table shows that the loading of factory overhead costs in 2018 is Rp. 29,325,600, - obtained from the allocation of the percentage of cost per mini pump unit and calculated from the previous table and multiplied by the total overall factory overhead costs in 2018. The factory overhead allocated to each unit of product will be used to calculate the cost of production of each product. The following is a table of cost of production according to Small and Medium EnterprisesUD.NewBusiness

Table 9

Cost of Production According to UKM in 2018

\begin{tabular}{|c|c|c|c|}
\hline \multirow{2}{*}{ Information } & \multicolumn{3}{|c|}{ Produt Types } \\
\hline & 1 Nosel & 2 Nosel & 3 Nosel \\
\hline Raw material Costs & Rp 12.550 .000 & Rp 502.000 .000 & Rp 71.400 .000 \\
\hline TKL Fee & 200.000 & Rp $\quad 4.000 .000$ & 300.000 \\
\hline Factoryoverhead fee & $\begin{array}{ll}\mathrm{Rp} & 1.173 .024 \\
\end{array}$ & Rp 26.099 .784 & 2.052 .792 \\
\hline Product Fee & $\begin{array}{ll}\text { Rp } & 13.923 .024 \\
\end{array}$ & Rp 532.099.784 & $\begin{array}{ll}\text { Rp } & 73.752 .792 \\
\end{array}$ \\
\hline Goods in the initial process & - & - & - \\
\hline Product Amount & Rp $\quad 13.923 .024$ & Rp 532.099.784 & Rp $\quad 73.752 .792$ \\
\hline Goods in the Final Process & - & - & - \\
\hline Costs of goods sold & Rp 13.923 .024 & Rp 532.099.784 & Rp 73.752 .792 \\
\hline Product Total Unit & $\mathrm{Rp}$ & $\mathrm{Rp}$ & $\mathrm{Rp}$ \\
\hline Cost of goods sold/Unit & Rp $\quad 6.961 .512$ & Rp 13.302 .495 & Rp $\quad 24.584 .264$ \\
\hline
\end{tabular}

Source: Research 2018

Based on the table above shows that the cost of production for a mini pump 1 nozzle is Rp. 6,961,512, - the cost of production for a mini pump 2 nozzles is Rp. 13,302,495, - and the cost of production for a mini pump 3 nozzle is Rp. 24,584,264, -

\section{h. Evaluating the Determination of Cost of Production by the Full Costing Method}

The calculation of the cost of production determined by SMEs uses the full costing method, but does not carefully calculate the factory overhead cost allocation or physical evidence in an approximate manner to determine the percentage amount.

This certainly affects the cost of production produced. The following is a recalculation of the factory overhead costs per unit of product produced using the method below:

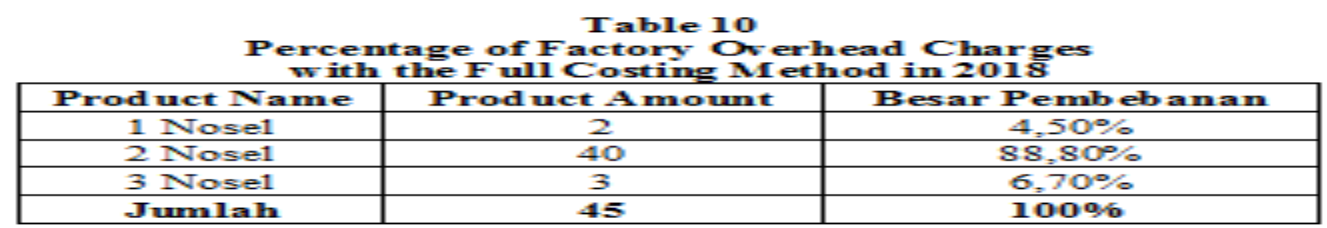

Source: Data from UD. Usaha Baru 
JARES, Vol. 4 No. 1 March, 2019; p-ISSN: 2502-826X; e-ISSN: 2503-1163

Copyrights@ Balitar Islamic University, Blitar, Indonesia;

https://ejournal.unisbablitar.ac.id/index.php/jares

Citation: Suprianto, S., Andari, B., \& Sulistyawati, Y. (2019). CALCULATION OF

PRODUCTION COST IN UD. USAHA BARU WITH FULL COSTING METHOD.

JARES (Journal of Academic Research and Sciences), 4(1), 28-42.

https://doi.org/10.30957/jares.v4i1.688

From the table above shows that a large percentage of the burden of factory overhead costs on SMEs UD. Usaha Baru allocated to each unit of mini pump products is $4.50 \%$ for mini pump units 1 nozzle, $88.80 \%$ for mini pump units 2 nozzles, and $6.70 \%$ for mini pump units 3 nozzles. The following are the results of the calculation of the total cost of loading factory overhead.

Table 11

Loading of Factory Overhead Costs According to the Theory of 2018

\begin{tabular}{|c|c|rr|}
\hline Product Name & Amount of loading & \multicolumn{2}{|c|}{ Total Amount } \\
\hline 1 Nosel & $4,50 \%$ & $\mathrm{R}_{\mathrm{p}}$ & 1.466 .577 \\
\hline 2 Nosel & $88,80 \%$ & $\mathrm{Rp}$ & 28.940 .453 \\
\hline 3 Nosel & $6,70 \%$ & $\mathrm{Rp}$ & 2.183 .570 \\
\hline Jumlah & $\mathbf{1 0 0 \%}$ & $\mathrm{Rp}$ & $\mathbf{3 2 . 5 9 0 . 6 0 0}$ \\
\hline
\end{tabular}

Source: Data processed from UD. Usaha Baru

The table is the loading of factory overhead costs for each unit of mini pump products produced based on calculations that are in accordance with the full costing method. In the next stage, the calculation of the cost of production for each type of product is in accordance with the previously calculated loading. The following table presents the calculation of cost of production at each unit of product assembly using the full costing method:

Table 12

Cost of Production According to Evaluation in 2018

\begin{tabular}{|c|c|c|c|c|c|}
\hline \multirow{2}{*}{ Information } & \multicolumn{5}{|c|}{ Jenis Produk } \\
\hline & & Nosel & 2 Nosel & & Nosel \\
\hline Raw Material Costs & & 12.550 .000 & Rp 502.000.000 & $R p$ & 71.400 .000 \\
\hline TKL Costs & $\mathrm{R}$ & 200.000 & Rp $\quad 4.000 .000$ & $R p$ & 300.000 \\
\hline Factory Overhead Costs & $\mathrm{R}_{1}$ & 1.466 .577 & Rp 28.940 .453 & Rp & 2.183 .570 \\
\hline Production Costs & $\mathrm{R}$ & 14.216 .577 & Rp 534.940.453 & $\mathrm{Rp}$ & 73.883 .570 \\
\hline Goods in the initial pr & & - & - & & - \\
\hline Production Amount & & 14.216 .577 & $\operatorname{Rp} 534.940 .453$ & $R p$ & 73.883 .570 \\
\hline Goods in the final Process & & - & - & & - \\
\hline Cost of good sold & & 14.216 .577 & Rp 534.940.453 & $\mathrm{Rp}$ & 73.883 .570 \\
\hline Production of Total Unit & $\mathrm{R}$ & 2 & $\mathrm{Rp}$ & $R p$ & 3 \\
\hline Costs of goods sold & $\mathrm{R}$ & 7.108 .289 & Rp 13.373 .511 & $R p$ & 24.627 .857 \\
\hline
\end{tabular}

Source: Researcher 2019 
JARES, Vol. 4 No. 1 March, 2019; p-ISSN: 2502-826X; e-ISSN: 2503-1163

Copyrights@ Balitar Islamic University, Blitar, Indonesia;

https://ejournal.unisbablitar.ac.id/index.php/jares

Citation: Suprianto, S., Andari, B., \& Sulistyawati, Y. (2019). CALCULATION OF

PRODUCTION COST IN UD. USAHA BARU WITH FULL COSTING METHOD. JARES (Journal of Academic Research and Sciences), 4(1), 28-42.

https://doi.org/10.30957/jares.v4i1.688

\section{Comparison of Cost of Production}

Based on the calculations made above, it can be known that there is a difference in the loading of factory overhead costs on each mini pump unit which is very significant. Because the difference in factory overhead costs will affect the cost of production of a product. The following below will be presented a recapitulation of the calculation of cost of production per type of product type

Table 13

Recapitulation of Comparison of Cost of Production

\begin{tabular}{|c|c|c|c|c|c|c|}
\hline Information & \multicolumn{2}{|c|}{ Based on UKM } & \multicolumn{2}{|c|}{$\begin{array}{l}\text { Full costing } \\
\text { Method }\end{array}$} & \multicolumn{2}{|c|}{$\begin{array}{c}\text { Selisih Harga } \\
\text { Pokok Produksi }\end{array}$} \\
\hline 1 Nosel & $\mathrm{Rp}$ & 6.961 .512 & $\mathrm{Rp}$ & 7.108 .289 & $\mathrm{Rp}$ & 146.777 \\
\hline 2 Nosel & $R p$ & 13.302 .495 & $\mathrm{Rp}$ & 13.373 .511 & Rp & 71.017 \\
\hline 3 Nosel & $\mathrm{Rp}$ & 24.584 .264 & $R p$ & 24.627 .857 & $\mathrm{Rp}$ & 43.593 \\
\hline
\end{tabular}

Source: Data processed from Tables 9 and 12

Based on the table of recapitulation of cost of production, it can be seen that there are differences or differences in the value of calculations according to SMEs and according to researchers using the full costing method. From these results the price difference for each mini pump product unit is obtained, including:

1. The price difference for a mini pump product 1 nozzle is Rp. 146,777 is higher than the calculation of cost of production according to UKM

2. The price difference for the mini nozzle pump product is Rp. 71,017 higher than the calculation of cost of production according to UKM.

3. The price difference for the mini nozzle pump product is Rp. 43,593 is higher than the calculation of the cost of production according to UKM.

From the results of the comparison of the cost of production of the production that has been carried out by SMEs with those conducted by researchers based on the full costing method, the conclusion is that UD. Usaha Baru has not charged engine maintenance costs, building maintenance costs, and vehicle maintenance costs that are not charged to factory overhead costs. This has resulted in the burden of SME factory overhead being too low. UD. Usaha Baru also carried out the basis of charging a percentage of factory overhead that was too high. Where this can affect the cost of production which is too high, resulting in too high a selling price to consumers. Because the overloading of factory overhead costs causes the production costs and cost of production to be too high so that it can reduce the profits earned by the UKM. In the long-term effect, charging too much can make consumers move to other products. 
JARES, Vol. 4 No. 1 March, 2019; p-ISSN: 2502-826X; e-ISSN: 2503-1163

Copyrights@ Balitar Islamic University, Blitar, Indonesia;

https://ejournal.unisbablitar.ac.id/index.php/jares

Citation: Suprianto, S., Andari, B., \& Sulistyawati, Y. (2019). CALCULATION OF

PRODUCTION COST IN UD. USAHA BARU WITH FULL COSTING METHOD. JARES (Journal of Academic Research and Sciences), 4(1), 28-42.

https://doi.org/10.30957/jares.v4i1.688

\section{CONCLUSION}

Based on the discussion of the evaluation of the determination of the cost of production, it can be concluded that the application of cost of production is very important for a business, especially for SMEs, because it can be used to assess the success of these SMEs. From the research that has been done, it can be concluded that:

1. UD. Usaha Baru is a Small and Medium Enterprises engaged in mini poma assembly (pertamini), which produces mini pump units so that it can make it easier for fuel retailers such as in stores for example. In the assembly process is divided into 3 , namely preparation in raw materials because each unit of the product has raw materials that are not the same amount, the assembly stage, and the completion stage in the feasibility of distribution.

2. In determining production costs at UD. Usaha Baru has used the full costing method, although it is not written neatly and in detail. In the prime cost calculation, it is in accordance with the existing theory or method. Whereas in factory overhead costs or direct production costs are not in accordance with the full costing method. This is evidenced by the costs of machine maintenance, costs in building maintenance, vehicle maintenance costs that have not been included in factory overhead costs.

3. In determining the percentage of factory overhead costs per unit of mini pump products at UD. Usaha Baru is based solely on the number of units a product is produced. So that there are no specific calculations in determining the loading of factory overhead costs. The loading calculated by the UKM with researchers is not the same because it experiences the difference in each unit of product produced, namely for the mini pump product 1 nozzle of Rp. 146,777 is higher than the calculation of cost of production according to UKM. For mini pump 2 nozzle products of Rp. 71,017 higher than the calculation of the cost of production according to UKM and for the mini nozzle pump product of Rp. 43,593 is higher than the calculation of the cost of production according to UKM. The results of the dispute occurred because the loading of SME factory overhead costs did not include machine maintenance costs, building maintenance costs, vehicle maintenance costs, and in determining the percentage of factory overhead for SMEs based on estimates of the number of production units produced per unit of product. 
Citation: Suprianto, S., Andari, B., \& Sulistyawati, Y. (2019). CALCULATION OF

PRODUCTION COST IN UD. USAHA BARU WITH FULL COSTING METHOD. JARES (Journal of Academic Research and Sciences), 4(1), 28-42. https://doi.org/10.30957/jares.v4i1.688

\section{REFFERENCESS}

Bustami, Bastian \& Nurlela (2010) Pengertian Harga Pokok Produksi Menurut Para Ahli. Diakses tanggal 03 Desember 2016 dari http://elib.unikom.ac.id/files/disk1/601/jbptunikomp-gldlinggalaya30015-9-unikm 1-i.pdf.

Carter, William. K. (2009). Akuntansi Biaya (Terjemahan), Buku 1, Edisi 14. Jakarta: Salemba Empat

Huda, Anam Miftakhul. Farida, N. (2018). Pengantar Ekonomi Mikro (Pertama). Pekalongan: NEM.

Huda, A. M., \& Martanti, D. E. (2018). Pengantar Manajemen Strategik 1. (J. Press, Ed.) (1st ed.). Bali: http://books.jayapanguspress.org/index.php/publisher/article/view/18/ $18 . \quad$ Retrieved from http://books.jayapanguspress.org/index.php/publisher/article/view/18/ 18

Ika Yulianti, Endah Masrunik, Anam Miftakhul Huda, D. E. (2018). IMPLEMENTASI JOB ORDER COSTING METHOD DALAM PERHITUNGAN HARGA POKOK PRODUKSI MAP. E-Ba Journal, 4(2), 43-55. Retrieved from https://ejournal.undar.ac.id/index.php/eba/article/view/613/417

Indriantoro, Nur, \& Bambang, S. (2009). Metodologi Penelitian Bisnis, Yogyakarta: BPFE Yogyakarta

Kurniasari, Dita, Huda, A. M. (2018). Analisis Perhitungan Harga Pokok Produksi dengan Metode Full Costing sebagai Penentu Harga Jual pada Produksi Opak Kembang Cap "KRESS ' NO ". Riset Dan Jurnal Akuntansi, 2(2), 1-15.

Mulyadi. 2010. Akuntansi Biaya Edisi 5. Yogyakarta: UPP STIM YKP

Rainborn, Cecily A. \& Kinney, Michael R. 2011. Akuntansi Biaya Dasar Dan Perkembangan, Buku 1, Edisi 7 (Terjemahan). Jakarta: Salemba Empat

Supriyono. 2000. Akuntansi Biaya, Buku 1 Edisi 2. Yogyakarta: BPFE Supriyono. 2004. Akuntansi Biaya Pengumpulan Biaya dan Penentuan Harga Pokok Produksi, Buku 1 Edisi 2. Yogyakarta: BPFE UGM. 